\title{
An assumed rheophytic orchid: Bulbophyllum rheophyton n.sp., from Borneo
}

\author{
Jaap J. Vermeulen · Hirokazu Tsukaya
}

Received: 7 September 2010/Accepted: 28 January 2011/Published online: 10 March 2011

(C) The Author(s) 2011. This article is published with open access at Springerlink.com

\begin{abstract}
Bulbophyllum rheophyton, sp. nov. (Orchidaceae) from Indonesian Borneo (Kalimantan) is described. The type was found in a river bed, just above the present water level, but clearly in a position where it would be flooded occasionally. Vegetatively, the plant is very slender when compared to other species within section Pahudia. We therefore assume that the species is adapted to a rheophytic lifestyle. This is novel within the megagenus Bulbophyllum.
\end{abstract}

Keywords Bulbophyllum $\cdot$ Borneo $\cdot$ Rheophyte

Politically, the island of Borneo is divided into an Indonesian part (Kalimantan), a Malaysian part (Sabah and Sarawak) and the state of Brunei. The island has an extraordinarily rich biodiversity but, sadly, much of its vegetation cover is destroyed. To protect ca. 240,000 ha of remaining forests in the border area, the three national governments signed the "Heart of Borneo" initiative in 2006. A 5-year program starting in 2009 aims to obtain detailed floristic information on the area through botanical expeditions, conducted by the Research Center for

J. J. Vermeulen ( $\square)$

NCB-Naturalis, Leiden Branch, National Herbarium

Netherlands, P.O. Box 9514, 2300 RA Leiden, The Netherlands

e-mail: vermeulen@nhn.leidenuniv.nl

H. Tsukaya

Graduate School of Science, University of Tokyo, Science Build \#2, 7-3-1 Hongo, Tokyo 113-0033, Japan

H. Tsukaya

National Institute for Basic Biology, Nishigo Naka 38, Okazaki,

Aichi 444-8585, Japan
Biology-Indonesian Institute of Sciences (LIPI). From December 2009 to January 2010, one of the authors (H.T.) participated in a survey of the Betung Kerihun National Park (West Kalimantan, north of Putussibau), which covers ca. 800,000 ha forest along the Sarawak border. The survey yielded several new taxa, e.g., a new genus Kalimantanorchis (Tsukaya et al. 2011), and a species of Bulbophyllum section Pahudia (Orchidaceae).

Many species of section Pahudia are primary forestfloor terrestrials, lithophytes or low-level epiphytes. The present species was found growing as a terrestrial in a river bed through primary forest, ca. $30-40 \mathrm{~cm}$ above the water level at the moment of observation. This was not during the height of the rainy season. The nearby river bank was covered with the rheophytic shrub Myrmeconauclea sp. (Rubiaceae), and rheophytic herbs such as Schismatoglottis sp., Aridarum burttii Bogner \& Nicolson, and Bucephalandra motleyana Schott (all Araceae), indicating that the river often floods well above the level at which the orchid species was found. The plant itself shows features that are possibly adaptations to survive the dynamic nature of this environment: rhizomes, pseudobulbs and leaves are relatively slender and flexible when compared to the other members of section Pahudia. In December 2010, H.T. visited the Betung-Kurihun National Park again and found that the species is locally common in the upper rheophytic zone, growing on tree trunks. We therefore assume that the species is adapted to a rheophytic lifestyle.

This is a new feature within the genus Bulbophyllum, and a very rare one among SE Asiatic orchids in general. We found only few records: Epipactis flava Seidenf. from Thailand is reported as 'the aquatic orchid' growing 'in streams', and it was speculated that is must be submerged for months (Seidenfaden and Pedersen 2003). Schuiteman (1997) lists Agrostophyllum laterale J.J. Sm. This species 


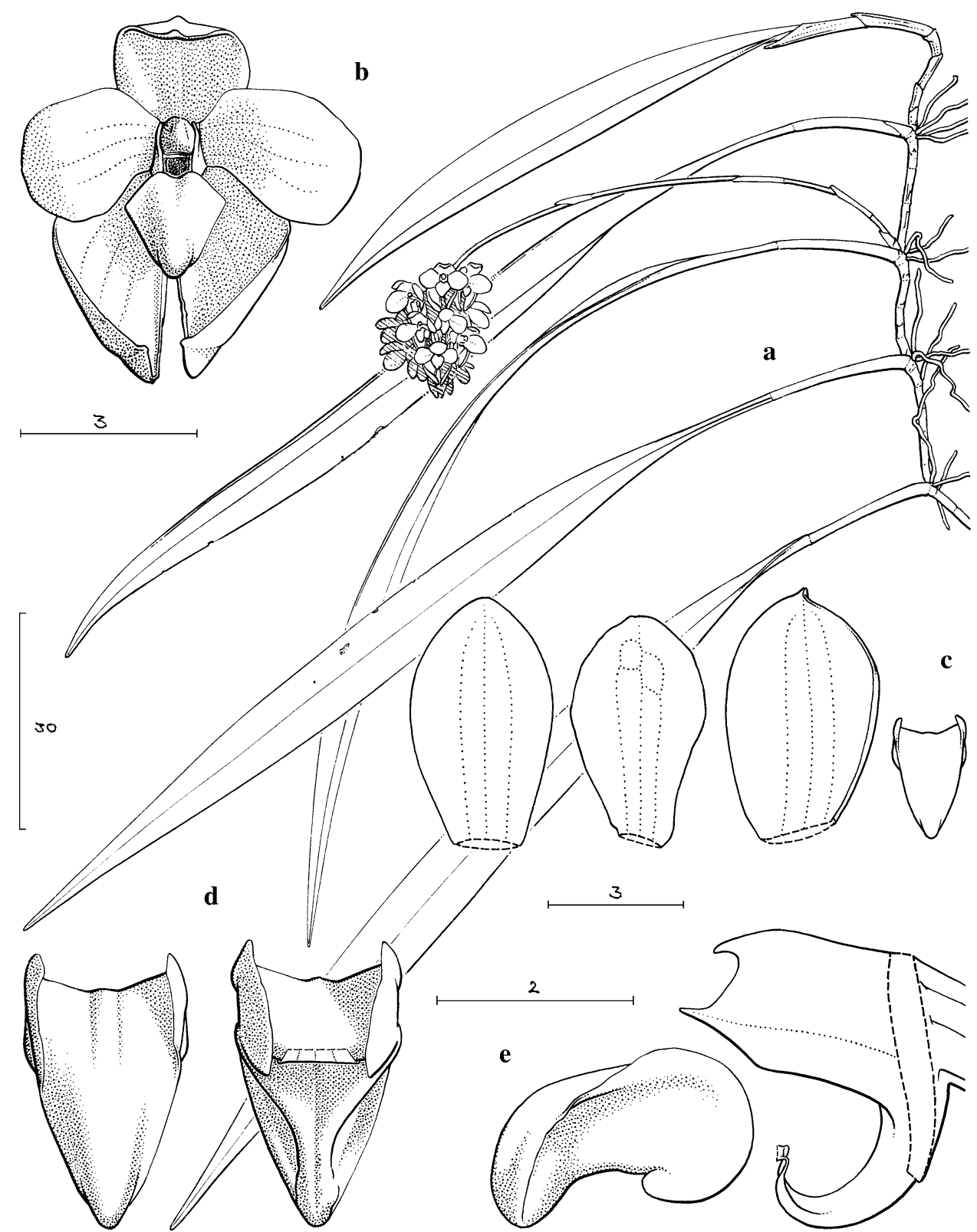

Fig. 1 Bulbophyllum rheophyton J.J. Verm. \& Tsukaya. a Plant; b flower; c flower analysis, from left to right: median sepal, petal, lateral sepal, lip; d lip: left adaxial side, right abaxial side; e column

displays adaptations to a rheophytic lifestyle (tough, matforming rhizomes and narrow leaves compared to its assumed closest relatives). Schuiteman doubts whether it is a strict rheophyte; we harbor the same doubt as to our Bulbophyllum section Pahudia. Facultative rheophytes, which occur close to the highest water line but only incidently just below, are more common: Arundina ceaspitosa Aver., Eria spirodela Aver. and Porpax elwesii (Rchb.f.) Rolfe, all three in Laos (Schuiteman, pers comm.), Poaephyllum celebicum J.J. Sm. and an unidentified Eria sp. and lip, lateral view. Drawn by J.J.V., (C2010, from Tsukaya 027 (spirit sample, photographs of herbarium and living plant)

section Conchidium in Sulawesi (J.J.V., personal observation).

Bulbophyllum mahakamense J.J.Sm., from Peninsular Malaysia, Sumatra and Borneo (see Seidenfaden and Wood 1992, p 487 for further information, under the synonymous name $B$. foetidolens Carr) is morphologically most similar to our rheophyte. We assume it is a sister species. B. mahakamense follows the environmental preferences of the section but has never been observed in a river bed so close to the water. Vegetatively, it is sturdier than our 
assumed rheophyte, but only statistically so, e.g., the leaf index (length/width) is 2.6-13 (mahakamense) versus 10-15.9. The best diagnostic difference between the two is found in the petals: apex subacute to acuminate, and index length/width 2.3-4.2 (mahakamense, 11 specimens measured), versus apex rounded, index ca. 1.6. The latter observation leads to the conclusion that our assumed rheophyte is indeed a separate species, rather than a rheophytic form of $B$. mahakamense.

Bulbophyllum rheophyton J.J. Verm. \& Tsukaya, sp. nov.-Type: Indonesia. Kalimantan, on the bank of a clear stream (Sungai Rongun), a branch of Mendalum River, NE of Putussibau, Kapuas Hulu $\left(01^{\circ} 01^{\prime} 57.5^{\prime \prime}-01^{\circ} 02^{\prime} 03.4^{\prime \prime} \mathrm{N}\right.$, $113^{\circ} 16^{\prime} 15.0^{\prime \prime}-113^{\circ} 95^{\prime} 48.9^{\prime \prime} \mathrm{E}$ ), 3 January 2010; Tsukaya 027 (holotype: BO; isotypes L, TI).

A Bulbophyllo mahakamensi petalis apice rotundato indice ca. 1.6 (contra 2.3-4.2) differt.

Roots mainly below the pseudobulbs. Rhizome $1-1.5 \mathrm{~mm}$ diam., sections between pseudobulbs $1.2-1.8 \mathrm{~cm}$ long, bract fibers barely persistent. Pseudobulbs distant, thinly cylindrical, somewhat flattened, $1.6-2.2 \times 0.2-0.3 \mathrm{~cm}$. Petiole 1.1-1.7 cm. Leaf blade elliptic (-ovate), 12-19 $\times$ $0.8-1.2 \mathrm{~cm}$, index (length/width) 10-15.9; acuminate. Inflorescence a dense raceme $9.5-10.8 \mathrm{~cm}, 15-20$-flowered. Peduncle patent, $8-9 \mathrm{~cm}$, bracts ca. 5 , the longest ca. $7 \mathrm{~mm}$ long. Rhachis slightly arching to nodding, $1.4-1.8 \mathrm{~cm}$. Floral bracts ovate, $2-2.5 \times$ ca. $1 \mathrm{~mm}$, acute. Flowers with the lip pointing to the top of the rhachis, but resupinate if rhachis nodding, rather widely opening, many simultaneously. Pedicel and ovary $2.5-3.5 \mathrm{~mm}$ long, basal node on an up to ca. $0.5 \mathrm{~mm}$ long stump, ovary ribs rounded, straight. Median sepal recurved, elliptic(-obovate), ca. $5.5 \times 3.3 \mathrm{~mm}$, index 1.6-1.7; rounded, margins entire, base rather narrowly attached; rather thin; glabrous. Lateral sepals free, oblique, obovate, ca. $5.5 \times 3.8 \mathrm{~mm}$, index 1.4-1.5; otherwise as the median sepal. Petals recurved, obovate, ca. $5 \times 3.1 \mathrm{~mm}$, index ca. 1.6; rounded, margins approximately entire, base narrowly attached; thin, glabrous. Lip slightly recurved in the distal half, ovate to sub-triangular, ca. $2.8 \times 1.7 \mathrm{~mm}$, index 1.6-1.7 (all without artificial spreading); obtuse, very thick, glabrous; adaxially slightly concave near the base, towards apex increasingly convex; abaxially with a high median ridge from base to tip, slightly retuse proximally and rounded elsewhere. Column ca. $2.2 \mathrm{~mm}$ long, stigma inside without keels, at its base without teeth, column foot without tooth just above the ligament. Stelidia triangular, ca. $0.7 \mathrm{~mm}$, acute, with a slight, deltoid, obtuse wing along the lower margin (Fig. 1).

Colors Flowers whitish, heavily mottled with reddish purple. Anther pale yellow.

Habitat Found as a terrestrial on a river bank, below flood level. Flowering observed in January.

Distribution Indonesia, Kalimantan, Kapuas River headwaters.

Acknowledgments The Secretariat of Permission for Foreign Research, The Ministry of Research and Technology, Republic of Indonesia (RISTEK), as well as the Indonesian Institute of Science (LIPI), kindly permitted field research in West Kalimantan. Prof. Hiroshi Okada conducted the botanical surveys leading to this paper. Dr. Dedy Daernadi of LIPI, Mr. Hapid of Bogor Botanical Garden, Mr. Mustar Udin, Mr. Suherman, and Mr. Ipin participated in the botanical surveys of the expedition. Mrs. Mutsuko Nakajima helped to identify the section to which this new species belongs and provided the first sketches.

Open Access This article is distributed under the terms of the Creative Commons Attribution Noncommercial License which permits any noncommercial use, distribution, and reproduction in any medium, provided the original author(s) and source are credited.

\section{References}

Schuiteman A (1997) Revision of Agrostophyllum section Appendiculopsis (Orchidaceae) with notes on the systematics of Agrostophyllum. Orchid Monogr 8:1-20

Seidenfaden G, Pedersen HA (2003) Contributions to the orchid flora of Thailand XIV. Nord J Bot 22:525-534

Seidenfaden G, Wood JJ (1992) The orchids of Peninsular Malaysia and Singapore. Olsen and Olsen, Fredensborg

Tsukaya H, Nakajima M, Okada H (2011) Kalimantanorchis: a new genus of mycotrophic orchid from West Kalimantan, Borneo. Syst Bot (in press) 